\title{
Effects of Added Katuk Leaf Powder and Cooking Oil on the Organoleptic Properties of Groundnut Biscuits
}

\author{
Ismi Ayu Nadhifa, Nugrahani Astuti \\ Department of Home Economics \\ Universitas Negeri Surabaya \\ Surabaya, Indonesia \\ nugrahaniastuti@unesa.ac.id
}

\begin{abstract}
Breastfeeding mothers need the additional food to increase the nutritional adequacy as well as to help the productivity of breast milk. Due to the lack of snacks, the production of biscuits is developed. This research focuses on the relation between katuk leaf powder and cooking oil on the organoleptic properties of groundnut biscuits. This study aimed to know the best product of organoleptic test result (shape, smell, color, crumb, crispness, taste and consumers' preference levels) and the nutrients (carbohydrate, energy, protein, fat, vitamin A, fiber and sesquiternat acid). This research used is experimental method, which done in the three stages; pre-experiment, preliminary and main research. It is followed by data collection in the two ways. First, organoleptic test was carried out with 30 panelists of Culinary Major and 100 breastfeeding panelists. Second, chemical tests conducted at Balai Penelitian dan Konsultasi Industri (BPKI), East Java. The result shows that there is relation that effect on the color, but not to other organoleptic elements. The effect of color interaction from leaf chlorophyll content, added with the same katuk leaf powder and the higher cooking oil indicating the better colour. So, the addition of katuk leaf powder can affect the colour of biscuit.
\end{abstract}

\section{Keywords—groundnut biscuit; katuk leaf powder; cooking oil}

$$
\text { I. }
$$

\section{INTRODUCTION}

Due to the lack of snacks, the production of groundnut biscuits is developed for breastfeeding mother. It can increase the nutritional adequacy as well as to help the productivity of breast milk. These additional nutrients are katuk leaf powder and cooking oil.

Some studies are conducted concerning on the use of katuk leaf. One of them is entitled "Performance and Egg Quality of Quail Offered Feed Containing Sterol from Katuk and Mulberry Leaf Meal" by Hermana [12]. They explain that the poultry produces eggs and meats with a good quality. It is also added by the nutrients of katuk and mulberry.

This research is good due to the adding of nutrients to the metabolism of poultry. However, there are some limitations on the adding of katuk's nutrients. They are not only good for poultry, but also for breastfeeding mothers.

Another reason is for the development of groundnut biscuits. As the filler, groundnut has good contents of energy, protein and fat to increase the need of nutritional for breastfeeding mothers. Nevertheless, the adequacy of those contents doesn't enough to fulfill their needs due to the lack of breast milk produced by pregnant women. To solve this problem, Javanese people often use katuk leaves as the consumption support for breastfeeding mothers. Katuk is usually consumed as the soup dish or even boiled. These dishes are too bored to be consumed, so that groundnut biscuits are created as snacks by adding of katuk leaves powder.

The benefit of katuk's nutritional content, as lactogagum, has been proven to be transmitter secretion on the breast milk or ASI [10]. The nutritional contents of katuk leaf can help to expedite the breast milk containing carbohydrate $11.00 \mathrm{~g}$, energy $59.00 \mathrm{cal}$, protein $4.80 \mathrm{~g}$, fat $1.00 \mathrm{~g}$, vitamin A $10,370.00 \mathrm{SI}$, fiber $204.00 \mathrm{mg}$. In addition, it also contains acid seskuiternat of $0.18 \mathrm{~g}$.

Groundnut contains much nutrients such as carbohydrates $23.60 \mathrm{~g}$, energy $559.00 \mathrm{cal}$, protein $26.90 \mathrm{~g}$, fat $44.20 \mathrm{~g}$, and fiber $74.00 \mathrm{mg}$ (Directorate of Nutrition MOH RI, 1981) that fulfill the needs of breastfeeding mothers. The basic ingredient of groundnut is cooking oil made from palm oil. It is used in the production of groundnut biscuits by adding katuk leaves powder. The addition and subtraction of the materials give the changing in physical characteristics that can be identified through the nature of organoleptic biscuit.

Groundnut biscuit, with the addition of katuk leaf powder and oil, has never been found in the market. As the food additives, katuk leaf powders in groundnuts are expected to produce as a good biscuit. It also can be accepted by the society, as one of the healthy snack. Based on the explanation above, it is necessary to conduct the research on "The Effect of Addition of Leaf Powder of Katuk (Sauropusandrogunus (L.) Merr.) and Oil to Organoleptic Properties of Groundnut Biscuits". Further, groundnut biscuits that added by katuk leaves powder and oil, will be tested organoleptically (form, aroma, colour, crumb, crisp and flavor). To determine the best result, it will be continued on the chemical test including carbohydrates, energy, fat, protein, vitamin A, fiber, and sesuruternat acid. 


\section{METHOD}

This research is experiment which is done in the three stages. First stage is pre-experiment 1 . It is aimed to find the standard recipe of groundnut that will be developed in the next stage. The second stage is the preliminary study. To manipulate the adding of katuk powder, the three best results are chosen to be continued in the main study. In this case, the main research means the continuation of the preliminary. It is added with the manipulation of total of groundnuts that are used in groundnut biscuits.

The variables of the research consist of: 1) independent variable (the addition of katuk leaf powder and oil), 2) dependent variable (the organoleptic properties of groundnut biscuits including shape, aroma, colour, crumb, crisps, taste and favorite level) and 3) control variables (the type and quality of ingredients consisting of low protein flour, sugar, milled sugar, katuk leaf powder), that are made by blanching them. Then, over all is baked until dry, sprinkled with the powder and cooking oil. There are two techniques to process the groundnuts. First, it is processed by using roasted techniques, thrown and crushed. Second, it is used the technique of making groundnut biscuits.

The design of experiment research is a $3 \times 2$ double factorial, as shown in Table I.

TABLE I . EXPERIMENTAL DESIGN

\begin{tabular}{|c|c|c|}
\hline $\begin{array}{c}\text { Addition of Katuk } \\
\text { Leaf Powder } \\
\text { (A) }\end{array}$ & \multicolumn{2}{|c|}{$\begin{array}{c}\text { Cooking Oil } \\
\text { (B) }\end{array}$} \\
\hline $\mathrm{A}_{1}$ & $\boldsymbol{B}_{1}$ & $\boldsymbol{B}_{2}$ \\
\hline $\mathrm{A}_{2}$ & $\mathrm{~A}_{1} \mathrm{~B}_{1}$ & $\mathrm{~A}_{1} \mathrm{~B}_{2}$ \\
\hline $\mathrm{A}_{3}$ & $\mathrm{~A}_{2} \mathrm{~B}_{1}$ & $\mathrm{~A}_{2} \mathrm{~B}_{2}$ \\
\hline & $\mathrm{A}_{3} \mathrm{~B}_{1}$ & $\mathrm{~A}_{3} \mathrm{~B}_{2}$ \\
\hline
\end{tabular}

There are two influenced factors. In the factor A, the addition of katuk leaf include three levels; 5\%, $10 \%$ and $15 \%$. In the factor $\mathrm{B}$, the addition of cooking includes two levels; $62.5 \%$ and $52.5 \%$ that are equal with the weight of wheat flour.

The data were collected in the two 2 ways; organoleptic test and chemical test. The organoleptic test is performed in 2 stages. First stage is to determine the best product and the second stage is see the best product on preferences level. The first stage organoleptic test was carried out the trained panelist of 15 lecturers and 15 semi-trained artists consisting of culinary students who already programmed in Bakery \& Pastry courses. Furthermore, based on phase 1 test, the preferred level of test (stage 2), performed on 100 breastfeeding panelists with an age range of 25-40 years. Chemical tests were performed on the best product of organoleptic test results. It was conducted in Balai Penelitian dan Konsultasi Industri (BPKI) of East Java.

\section{RESULTS AND DISCUSSION}

\section{A. Organoleptic Test}

The organoleptic test is performed to determine the best product and to see the best product preferences level.
- Shape

The expected shape criteria of biscuits are the shape and sharpness of the angle that based on the mold with a thickness of $\pm 7 \mathrm{~mm}$. The best results obtained are an average value of 3.43 biscuit and added with katuk leaf powder of $15 \%$ and oil $52.5 \%$. The average value of groundnut biscuit is presented in Figure 1.

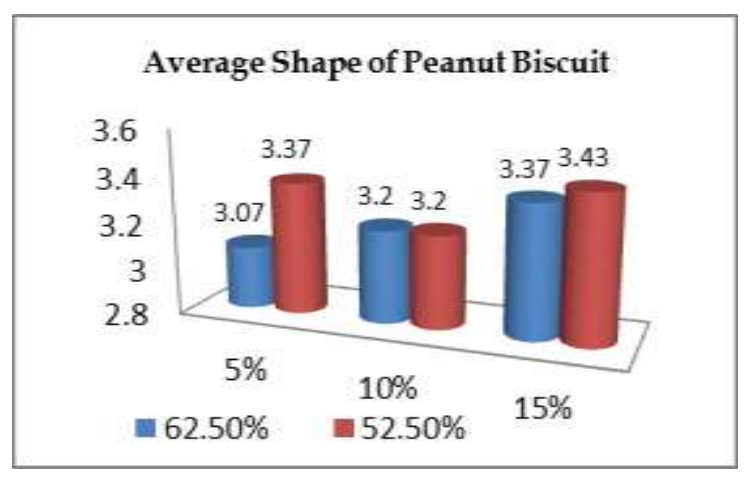

Fig. 1. Average Shape of Groundnut Biscuit Diagram

Furthermore, multiple anova tests were used to determine on the effect adding katuk leaves and cooking oil to groundnut biscuits. The results show that the addition of katuk leaf powder and oil do not affect the shape. It is indicated by the value of 0.585 with a significant level of 0.558 (above the real level of 0.05).

The shape of the biscuit is composed by the materials including wheat flour, groundnuts, oil and egg. An addition of katuk leaf powder of 5 to $15 \%$ and oil 52.5 to $62.5 \%$, produce the dough that is not physically different. When it is crushed, the dough will have the compact form. It will not cause to the changing of the biscuits after the canning process. It is caused by the use of some eggs which has a weight of $32 \mathrm{~g}( \pm 1 / 2$ grains). Indeed, it has no others developer ingredients. There is no water in the process of mixing, so that the shape of biscuits can't change as well.

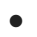

\section{Aroma}

The expected criteria of aroma are savory and flavorful nuts. The best results are obtained with an average value of 3.4 i.e. biscuit added with 5\% katuk leaf powder and oil of $62.5 \%$. The average value of groundnut biscuit aroma is presented in the diagram in Figure 2.

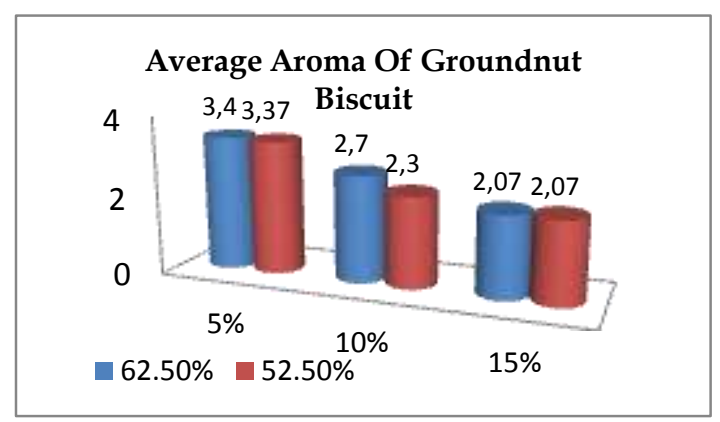

Fig. 2. Average Groundnut Biscuit Aroma Diagram 
Based on the calculation using double anova, the effect of katuk leaves powder and oil don't give the influence to its aroma. This is indicated by the value of $\mathrm{F}$ arithmetic of 1.586 with a significant level of 0208 (above the real level of 0.05).

The use of cooking oil and groundnuts cannot cover the whole aroma of katuk leaf. So, there is no effect regarding to the addition of katuk leaves and oil.

\section{- Colour}

The expected colours criteria are light green and slightly green speckled. The best results are obtained with an average value of 4.4 , i.e. biscuit with $10 \%$ leaf mixed powder and $52.5 \%$ oil. The average value of groundnuts biscuit color that added by katuk leaf powder and oil is shown in Figure 3.

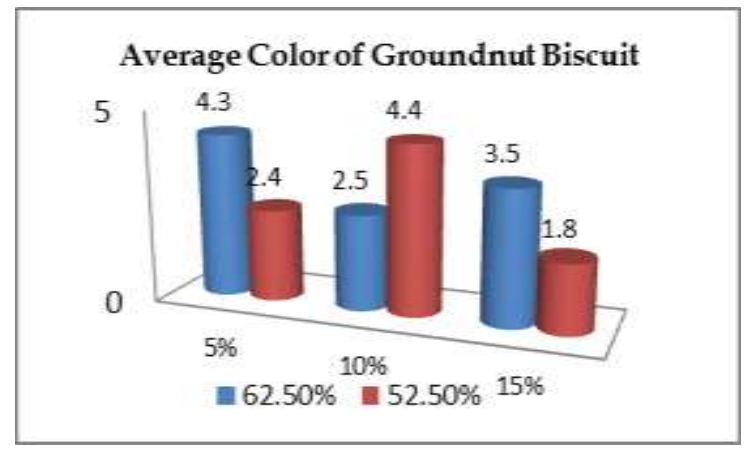

Fig. 3 Average Chart of Groundnut Biscuit Aroma

The result of double anova test shows the influence on color. This is indicated by the value of $\mathrm{F}$ arithmetic of 8,811 with a significant level of 0.000 (below the real level of 0.05 ). Duncan test is purposed to see the effect of katuk leaf powder and oil on the color of groundnuts biscuit.

Based on the results of Duncan's test, it can be seen that the use of katuk leaf powder with the addition of 5\%,10\% and $15 \%$ showed the different color of groundnut biscuit. In table 2 , a higher katuk leaves treatment have a low average value. The highest value is obtained from the third part of 5\%, which is added by katuk leave and a value of 3.6000.

The higher the total of katuk leaf powder, the lower the average value of the panelist on the valuation of biscuits' color. Plenty of katuk leaves will be added the green color that containing the contents of chlorophyll. Besides, the total of katuk leaf is equally same with the total of oil showing the better color. It can be influenced by its colour of katuk leaves that is the productive of green katuk leaves. So, the higher the total of katuki leaves will affect to the result of biscuits. The addition of green leaf powder of $15 \%$ shows the real colour. It is concentrated, so that an average value obtained is one including dark green and green speckled.

The addition of katuk leaf powder and cooking oil consisting of $5 \%, 62.5 \%$ and $5 \%, 52.5 \%$ show that there is the different on colour of groundnut biscuits by the increasing of $10 \%$. It is different as if added with $10 \%, 52.5 \%, 15 \%, 52.5 \%$ and $15 \%, 62.5 \%$. Based on Table 3 , it shows the higher treatment columns of katuk leaf and the lower oil average rating. The highest value is in the third subset of 5\% katuk leaf powder, added with a value of 3.6000

It can be concluded that the best result from the six treatments achieve the high score of 3.633. It is conducted by adding $5 \%$ of katuk leaf powder and $62.5 \%$ cooking oil. Those things are significantly affected to the colour of biscuits.

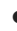

Crumbs

The expected crumb criteria are easily broken and crumbled when it is flattened with good grains. The best results are obtained with an average rating of 3.47 i.e. biscuit with $5 \%$ katuk leaf powder and oil of $62,5 \%$. The average value of groundnut biscuit crumbs added with katuk leaf and oil powder is presented in the Figure 4.

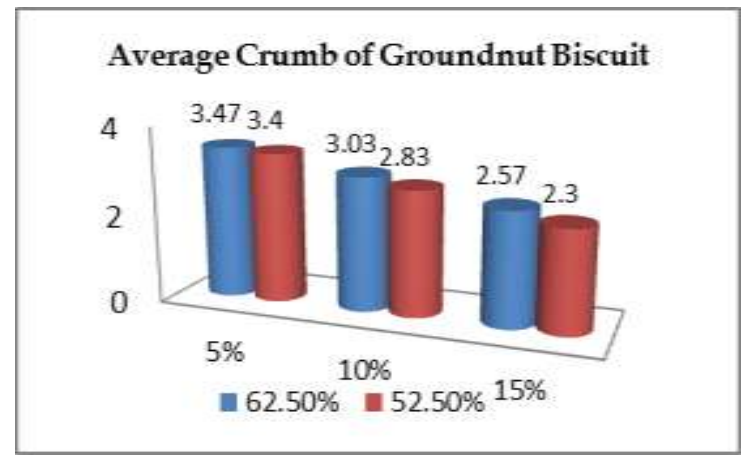

Fig. 4 Average Chart of Groundnut Biscuit Crumb

Results from multiple anova tests shows that there is no effect on crumbs. This is indicated that the value of $\mathrm{F}$ arithmetic of 0.196 with a significant level of 0.823 (above the real level of 0.05 ).

As seen in figure 4, the higher the total of katuk leaf powder, the lower the average value of the panelists on the valuation of biscuit crumbs. This is influenced by the composition of ingredients in biscuit. The addition of much dry ingredients and liquid will result slurry dough. Whereas the addition of enough dry ingredients and also liquid will result a dense mixture. However, the addition of katuk leaf powder and oil has no effect due to its addition of $5-15 \%$ of the weight of wheat flour. In other words, a little addition will not effect on the crumbs of groundnut biscuits.

\section{- Crispness}

The expected criteria of crispness are crunchy and easily crumbled when it is chewed. The best results are obtained with an average value of 3.57 i.e. biscuit with $5 \%$ katuk leaf powder and oil $62.5 \%$ and $52.5 \%$. The average value of crispy groundnut biscuit, added by of katuk leaf powder and oil is shown in the Figure 5.

Results from multiple anova tests shows that there is no effect on crispness. This is indicated that the value of $\mathrm{F}$ arithmetic of 0.637 with a significant level of 0.530 (below the real level of 0.05). 


\section{Average Crispy of Groundnut Biscuit}

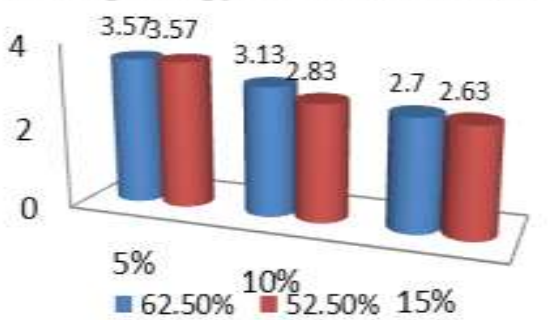

Fig. 5. Average Crispy Groundnut Biscuit

In Figure 5, the higher the total of katuk leaf powder, the lower the average value of the panelist on the evaluation of crisp biscuits. This is influenced by the composition of ingredients on biscuit. The addition of katuk leaf powder and oil on crumbs as well as on crispness also has the same factor. It is because the addition of katuk leaf powder is only $5-15 \%$ of the weight of wheat flour. In other words, a little addition will not effect on the crispness of groundnut biscuits.

\section{Flavor}

The expected taste criterion is very tasty. The best results are obtained with an average value of 3.03 that is biscuit with $5 \%$ katuk leaf powder and $52.5 \%$ oil. The average value of groundnut biscuit flavors, added with katuk leaf powder and oil is shown in Figure 6.

Results from multiple anova tests showed that there is no effect on taste. This is indicated by the value of $F$ arithmetic of 0.292 with a significant level of 0.747 (above the real level of 0.05 ). The higher the total of katuk leaf powder, the lower the average value of the panelist to the taste of the biscuits. The addition of katuk leaf powder is about $5-15 \%$ of the weight of wheat flour. In other words, a little addition will not affect the taste of biscuits.

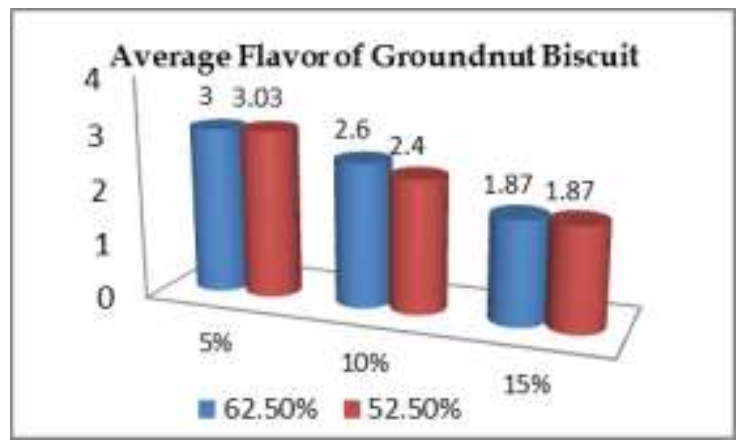

Fig.6. Flavor Aroma of Groundnut Biscuit

\section{- $\quad$ Preference level of Groundnut Biscuit}

The result of the favorite test obtained are presented in the percentages including 1) criterion 4 (like) of $61 \%$, criterion 3 (quite like) of $25 \%$, criterion 2 (less like) of $14 \%$, and criterion 1 (do not like) of percentage $0 \%$. The result of test of respondent's level in the percentage form can be seen in Table II.
TABLE II. RESPONDENTS PREFERENCE LEVEL

\begin{tabular}{|l|c|c|}
\hline \multicolumn{1}{|c|}{ Preference Level } & Frequency & Percentage \\
\hline 4 (like) & 61 & $61 \%$ \\
\hline 3 (Quite like) & 25 & $25 \%$ \\
\hline $\begin{array}{l}\text { 2 (do not like it } \\
\text { much) }\end{array}$ & 14 & $14 \%$ \\
\hline 1 (do not like) & 0 & 0 \\
\hline Total & 100 & $100 \%$ \\
\hline
\end{tabular}

$B$. Chemical Test

Nutritional content of groundnut biscuit is presented in Table III.

TABLE III. COMPARISON OF NUTRITIONAL CONTENT OF BISCUIT

\begin{tabular}{|c|l|c|c|}
\hline No & \multicolumn{1}{|c|}{ Nutrient } & $\begin{array}{c}\text { Groundnut } \\
\text { Biscuit }\end{array}$ & $\begin{array}{c}\text { Groundnut Biscuit Added } \\
\text { with Katuk Leaf Powder } \\
\text { and Cooking Oil }\end{array}$ \\
\hline 1 & Karbohidrat (\%) & 68.12 & 66.34 \\
\hline 2 & Energi (kal) & 426.80 & 466.50 \\
\hline 3 & Protein (\%) & 6.88 & 7.86 \\
\hline 4 & Fat (\%) & 14.12 & 14.56 \\
\hline 5 & Vitamin A (mg) & 57.80 & 98.60 \\
\hline 6 & seskuiterna acid (\%) & - & 0.18 \\
\hline 7 & Fiber (\%) & 2.48 & 4.82 \\
\hline
\end{tabular}

Chemical tests are performed in the best product samples, added with 5\% katuk leaf powder $(20 \mathrm{~g})$ and oil of $62.5 \%(250$ g). Nutritional content tested include carbohydrates, energy, protein, fat, vitamin A, sesuruterna acid, and fiber. Chemical tests are conducted at Balai Penelitian dan Konsultasi Industri (BPKI), Surabaya. It is carried out 100 grams for each biscuit.

\section{CONCLUSION.}

The addition of katuk leaf powder and oil affect the color, however, it does not effect on the shape, aroma, crumb, crispness, and taste. The best groundnut biscuit product is added with $5 \%$ katuk leaf powder and oil of $62.5 \%$. It is obtained based on the nutrient content of $66.34 \%$ carbohydrate, $466.5 \%$ energy, $7.86 \%$ protein, $14.56 \%$ fat, $98.60 \mathrm{mg}$ vitamin A, $0.18 \%$ sesuranerna acid and $4.82 \%$ fiber.

\section{REFERENCES}

[1] Ajibola, C.F., Oyerinde, V.,O.,Adeniyan, O.,S. "Physicochemical and Antioxidant Properties of Whole-Wheat Biscuits Incorporated with Moringaoleifera Leaves and Cocoa Powder". Journal of Scientific Research \& Reports 7(3): 195-206, 2015. www.sciencedomain.org

[2] Andaka, Ganjar. "Optimasi Proses Ekstraksi Minyak Kacang Tanah dengan Pelarut N-Heksana.’Jurnal Teknologi, Volume 2 Nomor 1, pp $80-88$

[3] Bloom, Carole. The Essential Baker. New Jersey: John Wiley \& Sons, Inc, Hoboken.2007.

[4] Canalisa, M.S.B., "Leon, A.E.,Ribotta, P. D. Effect of inulin on dough and biscuit quality produced from different flours". International Journal of Food Studies (IJFS). April 2017 Volume 6 pages 13-23

[5] Chugh,B. Singh, G. and "Kumbhar B.K.Deve-lopment of Low-Fat Soft Dough Biscuits Using Carbohydrate-Based Fat Replacers" International Journal of Food Science.12 pages. 2013http://dx.doi.org/10.1155/2013/576153 
[6] Conforti, F. D., Charles,S. A. and Dunkan,S. E. "Sensory evaluation and consumer acceptance of carbohydrate-based fat replacers in biscuits", Journal of Consumer Studies and Home Economics, vol. 20, pp. 285-296, 1996. V

[7] Fauziah, Anik. "Pengaruh Perbandingan Tepung Kacang Tunggak dengan Tepung Mocaf dan Persen Jumlah Lemak (Margarin dengan Butter) Sifat Organoleptik Rich Biscuit (Biskuit Berlemak)”. Skripsi tidak diterbitkan. Surabaya: PPs Universitas Negeri Surabaya.2015.

[8] Hardjanti, Sri. "Encapsulasi Ekstrak Daun Katuk (Sauropus androgynous (L) Merr) sebagai Bentuk Sediaan Praktis bagi Ibu Menyusui dan Kinetika Kerusakannya”. Laporan Penelitian Dikti. Perpustakaan Universitas Indonesia. 2008.

[10] Hardjanti, Sri. "Potensi Daun Katuk sebagai Sumber Zat Pewarna Alami dan Stabilitasnya Selama Pengeringan Bubuk dengan Menggunakan Binder Maltodekstrin”. Jurnal Penelitian Saintek, Vol. 13, No. 1, hal 118.2008

[11] Hassell, C.A. "Nutritional implications of fat substitutes," Cereal Foods World, vol. 38, pp. 142-144, 1993.

[12] Hermana, Toharmat et al. "Performances and Egg Quality of Quail Offered Feed Containing Sterol form Katuk (Sauropus androgynous) and Mulberry (Morusalba) Leaf Meal”. Internasional Journal of Poultry Science 13(3): 168-172, 2014.

[13] Kanetro \& Hastuti. “Ragam Produk Olahan Kacang-Kacangan”. Yogyakarta: Unwama Press.2006.

[14] Kar,S., et all. "Utilization of Moringa Leaves as Valuable Food Ingredient in Biscuit Preparation". International Journal of Applied Sciences \& Engineering (IJASE) 1(1): April, 29-37. 2013.

[15] Ketaren, S. "Pengantar Teknologi Minyak dan Lemak Pangan". Jakarta: UI-Press.. 1986

[16] Lamadlauw dan Arief. Pastry and Bakery Production. Yogyakarta: Grahallmu.2004.

[17] Nwosu, Justina N. "Production and Evaluation of Biscuits from Blends of Bambara Groundnut (Vigna Subterranae) and Wheat (Triticum
Eastrum) Flours". International Journal of Food and Nutrition science vol 2 No 1 March. 2013

[18] Okoye, J. I., Ojimelukwe, P. C., and Ukom, A. N. "Nutritional Quality of Wheat Biscuits Fortified with Soybean and Bambara Groundnut Flours". International Journal of Applied Research and Technology. y. 5(3): $65-72.2016$

[19] Pangesti, Lucia Tri. "Biscuit.Bahanajar tidak diterbitkan". Surabaya: UniversitasNegeri Surabaya.2013

[20] Sadaf, J., et all. "Groundnut butter incorporation as substitute for shortening in biscuits: Composition and acceptability studies". International Food Research Journal 20(5): 3243-3247. 2013

[21] Soepartini. Endang. 1990. Kumpulan ResepPribadi. Tidak diterbitkan. Trenggalek.2003.

[22] Sukeerthi,S.S., Singh, J. Formulation and nutritional analysis of biscuits made from quinoa, flax seed and brown rice. International Journal of Food Science and Nutrition: 2 2; 27-30; 2017

[23] Wulandaridan Erma Handasari. "PengaruhPenambahanBekatulterhadap Kadar Protein dan Sifat Organoleptik Biskuit”. JurnalPangandanGizi. Vol 01 No. 02: hal. 55-62.2010

[24] Yadav,D.N., Thakur, N., Sunooj, K.V.. "Effecct of Partially De-Oilled Groundnut Meal Flour (DPMF) on The Nutritional, Textureal", Organoleptic and Physico Chemical Properties of Biscuits. International Food Research Journal 20(5): 3243-3247.2013

[25] Wiradimadja, Rachmat. "Potensi Tanaman Katuk (Sauropus androgynous L.Merruntuk Meningkatkan Kualitas Intensitas Warna Kuning Telur. Lokakarya Nasional Pengembangan Jejaring Litkaji Sistem Integrasi Tanaman - Ternak Jurnal UPI201

[26] Yenrina, R., Sayuti, K.,Ningsih, W.. Fe "Content and Antioxidant Activity of Cookies with addition of Banana (Misa Paradisica) Flour and Katuk (Souropus Androgynous) Leaves Flour". International Journal of Advanced Research. 5(8); 327-334. 2017 